\title{
Utilization of Oil Palm Empty Fruit Bunch (EFB) as Spodosol Soil Ameliorant for Increasing Oil Palm Root Growth
}

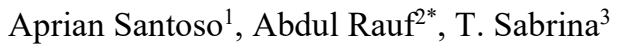 \\ Graduate School of Agrotechnology, Universitas Sumatera Utara, Indonesia ${ }^{1}$, \\ Department of Agriculture, Universitas Sumatera Utara, Indonesia ${ }^{2,3}$ \\ *a.raufismail@gmail.com
}

\begin{abstract}
Spodosol soil is a marginal soil that can be used for the cultivation of oil palm plants which has economic value. Spodosol soil has the physical characteristics of quartz sand and harpand, with both dominance characteristics leads unoptimal oil palm root development . This study was aimed to analyze the effect of oil palm empty fruit bunch, material organic as an ameliorant. Unmanaged EFB will become a breeding site of Oryctes rhinoceros. 3 levels treatments in this study : 30 tons/ha of EFB, 40 tons/ha of EFB and 45 tons/ha were applicated in 2 different placement, around the palms weeded circle and oil palm strip . According to root dry weight there is no significant difference for 3 treatment applied. 35 tons/ treatment applied in oil palms strip indicate the best result than the other dosages.
\end{abstract}

Keywords : empty fruit bunch, oil palm, spodosol soil

\section{Introduction}

Spodosol land is currently an alternative for oil palm cultivation business due to limited fertile land. Spodosol is low fertility soil, properly selection and conservative treat suggested so that it cultivation on spodosols has economic value. Statement of [1] composition of spodosol soil characteristics such as ; carbon content (C) which is rather low (0.11-1.31\%) and rather high $(4.62 \%)$ on the spodic horizon, the low to moderately low Nitrogen $(\mathrm{N})$ content $(0.10-0.11 \%), \mathrm{C} / \mathrm{N}$ ratio is rather low $(0.10-0.11 \%)$ in the upper layer and high in the spodic layer $(46.2 \%)$, the low phosphorus $(\mathrm{P})(1-8 \mathrm{ppm})$ availability in all layers, cation exchange capacity (CEC) classified as low to moderate in the entire horizon (7.64-14.98), the low base saturation (KB) (1-3) \%), an acidic soil $\mathrm{pH}(\mathrm{pH} 3.7-4.5)$ in all layers.

The previous study on spodosol soil on Central Kalimantan[2], states that the soil texture of the whole spodosol soil profiles located at PT. Sawit Graha Manunggal (SGM) East Barito regency, dominated by sand with medium category of Bulk Density (BD) and soil permeability categoryis moderately rapid permeability to rapid permeability to. Soil chemical parameters include $\mathrm{pH}, \mathrm{N}(\%), \mathrm{C}(\%), \mathrm{C} / \mathrm{N}, \mathrm{CEC}, \mathrm{P}$-total and P-available andcategory of base exchang is low to very low

Palm Oil Mill is not only producing CPO products and kernels, but alsoan organic waste mill such as Empty Fruit Bunch (EFB), Palm Oil Mill Efluent (POME), and Shell . These wastes if it not managed properly, it can be a problem sources around oil palm plantations. 
The utility of EFB as an organic amelioration in spodosol soils was aimed to improved soil fertility and prevent EFB from becoming a breeding site or horn beetle pests. If the EFB is stacked an unused, it will become a breeding site of O.rhinoceros. this previous study [3], shows that applicating of $200 \mathrm{~kg}$ of EFB / tree or $100 \mathrm{~kg}$ of EFB compost /tree and combined with the implementation of Best Management Practices provides a trend of increasing crop productivity in spodosol soil.

The roots of the oil palm not only serve as a propoil palmbody but also as an absorber of nutrients and water in the soil for oil palm growth development. Roots are one of the important factors in determining crop productivity [4]. The more extensive a root system, the higher efficiency of plantnutrients and watertake.

Previous study [5] describe the size of the roots, oil palm roots are divided into 4 (four) parts, namely 1) primary roots, roots that grow vertically (adventitious roots) and horizontal (adventitious roots), 6-10 $\mathrm{mm}$ in diameter; 2) secondary roots are roots that grow from the primary root, the direction of growth horizontally or downward, 2-4 $\mathrm{mm}$ in diameter; 3 ) tertiary roots are roots that grow from secondary roots, the direction of growth is horizontal, its reach 0.7 - $2 \mathrm{~mm}$ in length; 4) Quaternary roots are branch roots of tertiary roots, having a diameter of $0.1-0.3 \mathrm{~mm}$ andaverage of length $3 \mathrm{~cm}$

\title{
2 Research Method
}

This research was conduct in Sawit Graha Manunggal Estate, Sub District North Barito - Central Kalimantan and it started on 2014 with 10 years old of oil palm. The application of EFB is carried out in two difference places, around the palms weeded circle and oil palm strip The dosages level of this study are E1:30 tons/ha as a control (the standard dose for oil palm) ; E2:35 tons/ha and 40 tons/hectare and no dose as a comparison. 30 tons / ha as a control because plants. Each treatment was repeated 3 times.EFB aplicaation around the oil palms circle path is arranged evenly in one layer with 2 meter radius area, while the application oil palm inter row arranged evenly in a layer between the inter row (plant path).

The root development in FEB layer application and on the soil boundary layer of the EFB in 0-20 cm depth has been observed.Sampling was taken at the EFB application area by making a 1 meter $x 1$ meter plot, roots taken at the EFB layer area and soil depth 0-20 cm. Then the roots are cleaned from the soil and organic EFB then dried using an oven at temperature of $80{ }^{\circ} \mathrm{C}$.

\section{Results and Discussion}

\author{
3.1 Root dry weight \\ Data on dry weight of oil palm plant roots in the results of the research sample as shown \\ in Table 1.
}


Table 1.Number of root dry weight in different dosage level and placement of EFB in oil palm

\begin{tabular}{lcccc}
\hline \multicolumn{1}{c}{$\begin{array}{c}\text { Aplicating } \\
\text { Places of EFB }\end{array}$} & Dosage & Eevel & & \multicolumn{3}{c}{ (gr) } & \\
\cline { 3 - 5 } Oil Palm inter row & & & & \\
& E1 & 245.00 & 635.00 & 880.00 \\
& E2 & 191.67 & $\mathbf{7 2 4 . 0 0}$ & $\mathbf{9 1 5 . 6 7}$ \\
& E3 & 301.67 & 373.33 & 688.33 \\
Average & 246.11 & 577.44 & 828.00 \\
Oil Palm Circle & E1 & $\mathbf{3 2 0 . 0 0}$ & 402.33 & 722.33 \\
Path & E2 & 278.00 & 438.33 & 716.33 \\
& E3 & 264.67 & 595.67 & 860.33 \\
& Average & 287.56 & 478.78 & 766.33 \\
Average All & & & & \\
\hline
\end{tabular}

Root distribution is generally greater at $0-20 \mathrm{~cm}$ depth than EFB area to the soil surface. According to total dry root weight, it was heavier on oil palm inter row than on palm circle path. Generally the treatment on palm circle path is always cleaner than on oil palm inter row. Palm circle path area is the place where the fruit falls and since it to easier the operational activities of fruit citing, the palm circle path must be clean from organic waste or growing weeds. Otherwise on palm strip is fully of organic matter by the leaves. This study is agree to [6] that most active roots are at a depth of $5-30 \mathrm{~cm}$ and tertiary roots are at $10 \mathrm{~cm}$ from the soil surface where there is a lot of organic matter.

Refers to Table 1. the amount of dry root weight in the EFB application area is smaller compared to the number of roots at a depth of $0-20 \mathrm{~cm}$. Roots in the EFB layer are quarter roots that are smaller than roots at a depth of $0-20 \mathrm{~cm}$, namely secondary and tertiary roots. As a comparison, researchers also took root samples in plants that were not applied to EFB, in Table.2 as follows:

Table 2. Root dry weight in non EFB aplicated

\begin{tabular}{|l|ccc|}
\hline Non & EFB -0 & $0-20 \mathrm{~cm}$ & Total \\
\cline { 2 - 4 } EFB & \multicolumn{3}{|c}{ (gr) } \\
\cline { 2 - 4 } Aplicated & 0 & 529,17 & 529,17 \\
\hline
\end{tabular}

If we compared the number of total dry root weight on Table 1. and Table 2.It was higher within applied EFB than without EFB application. Low spodosol soil fertility inhibits the growth of oil palm roots. With a high sand texture, spodosol availability of nutrients and ground water is very poor that causesevaporation and soil erosion are easier.

The addition of EFB as anorganic amelioration of soil also adds nutrients and maintains moisture in the spodosol soil. In line with the statement [7] that the highest number of roots is under the EFB pile or midrib where the concentration of organic matter from weathering and microorganism activity are high.However, genetic and environmental factors such as temperature, soil moisture and soil softness also affect the length of root path absorption which can affect root development[8]. The movement and distribution of roots in the soil are interconnected with water availability and nutrient availability. The most effective nutrient uptake is carried out by tertiary and quarter roots called feeding roots of approximately 0.2 1.2 millimeter in diameter which are generally more abundant in top soil [9]. 


\subsection{Root Dry Weight in the Layer Area of the EFB Application}

Data on the results of various observations of dry root weight in the EFB application layer as in Table 3.as follows:

Table 3. Analysis of Variance . Main plot coefficient of variance $=18 \%$, sub plot coefficient of variance $=1,1 \%$

\begin{tabular}{|c|c|c|c|c|c|c|c|}
\hline \multirow{2}{*}{ Source Variance } & \multirow{2}{*}{$\mathrm{dF}$} & \multirow{2}{*}{ Sum of Square } & \multirow{2}{*}{ Mean Square } & \multirow{2}{*}{ F Value } & & \multicolumn{2}{|c|}{ F Ratio } \\
\hline & & & & & & 0,05 & 0,01 \\
\hline Main plot & 5 & 86275,83 & 17255,17 & 0,86 & tn & 19,30 & 99,30 \\
\hline Replication & 2 & 38574,33 & 19287,17 & 0,97 & tn & 19,00 & 99,00 \\
\hline Aplication Placement (P) & 1 & 7729,39 & 7729,39 & 0,39 & tn & 18,51 & 98,50 \\
\hline error (a) & 2 & 39972,11 & 19986,06 & & & & \\
\hline Aplication Dosage (D) & 2 & 9217,33 & 4608,67 & 0,38 & tn & 4,46 & 8,65 \\
\hline$P \times D$ & 2 & 13941,78 & 6970,89 & 0,58 & tn & 4,46 & 8,65 \\
\hline eror (b) & 8 & 96113,56 & 12014,19 & & & & \\
\hline Total & 17 & 205548,50 & & & & & \\
\hline
\end{tabular}

According to Table 3. there is no significant differences between the level treatment (doses) among E1, E2 and E3 at the alpha value of 5\% and 1\%. However, the best treatment is in the E1 treatment of the palm circle path area sinceat the time applying inorganic fertilizer around the palm circle path area there are more nutrients than around in palm inter row .Nutrients given by inorganic fertilizers are earlier dissolved, so that quarter root is the more active to absorb higher nutrients in palm circle path area. The level of E1 (EFB 30 tons/ha) also has no significant effect on the decomposition process and nutrient coverage of organic fertilizer on roots.

\subsection{Root Dry Weight in Layer Area 0 - $20 \mathrm{~cm}$}

To evaluated this parameters, the sample was taken from EFB layer barrier see Table 4.

Table 4. Analysis of Variance . Main plot coefficient of variance $=19 \%$, sub plot coefficient of variance $=1,8 \%$

\begin{tabular}{|c|c|c|c|c|c|c|c|}
\hline \multirow{2}{*}{ Souce of variance } & \multirow{2}{*}{$\mathrm{dF}$} & \multirow{2}{*}{ Sum of Square } & \multirow{2}{*}{ Mean Square } & \multirow{2}{*}{$\mathrm{F}$ Value } & & \multicolumn{2}{|c|}{ F Ratio } \\
\hline & & & & & & 0,05 & 0,01 \\
\hline Main plot & 5 & 580567,11 & 116113,42 & 1,26 & tn & 19,30 & 99,30 \\
\hline Replication & 2 & 352256,78 & 176128,39 & 1,91 & tn & 19,00 & 99,00 \\
\hline Aplicating placement $(\mathrm{P})$ & 1 & 43808,00 & 43808,00 & 0,47 & tn & 18,51 & 98,50 \\
\hline Eror (a) & 2 & 184502,33 & 92251,17 & & & & \\
\hline Aplication Dosage (D) & 2 & 28836,11 & 14418,06 & 0,12 & tn & 4,46 & 8,65 \\
\hline PX D & 2 & 233949,00 & 116974,50 & 0,98 & tn & 4,46 & 8,65 \\
\hline Eror (b) & 8 & 950641,56 & 118830,19 & & & & \\
\hline Total & 17 & 1793993,78 & & & & & \\
\hline
\end{tabular}


There is no significant effect between the treatment levels of dose E1, E2 and E3 at the alpha level of 5\% and 1\%. According to Table 1.indicate that the highest weight of root is in the E2 dosage (EFB 35 tons/ha) which is applied on the oil palm inter row. This is due to the fact that there are a lot organic material decomposes until it reaches $20 \mathrm{~cm}$ depths. The dominant root at a depth of $0-20 \mathrm{~cm}$ is the tertiary root, [6] which stated that most active roots are at a depth of $5-30 \mathrm{~cm}$ and tertiary roots are at $10 \mathrm{~cm}$ from the soil surface where there is a lot of organic matter. E2 level dose (EFB 35 tons/ha) applied around the oil palm inter row is more optimal for the growth of roots, due to weathering and holding water better, so that decomposed organics are not easily eroded vertically and horizontally.

\subsection{Total Dry Root Weight}

Furthermore variance data for total root dry weight are listed in Table 5. below as follows

Table 3. Analysis of Variance . Main plot coefficient of variance $=7 \%$, sub plot coefficient of variance $=$ $1,4 \%$

\begin{tabular}{|c|c|c|c|c|c|c|c|}
\hline \multirow{2}{*}{ Sources of Variance } & \multirow{2}{*}{$\mathbf{d F}$} & \multirow{2}{*}{ Sum Square } & \multirow{2}{*}{ Mean Square } & \multirow{2}{*}{ F Value } & & \multicolumn{2}{|c|}{ F Ratio } \\
\hline & & & & & & 0,05 & 0,01 \\
\hline Main plot & 5 & 691525,83 & 138305,17 & 5,07 & tn & 19,30 & 99,30 \\
\hline Replication & 2 & 619843,00 & 309921,50 & 11,36 & tn & 19,00 & 99,00 \\
\hline Aplication Placement (P) & 1 & 17112,50 & 17112,50 & 0,63 & tn & 18,51 & 98,50 \\
\hline Eror (a) & 2 & 54570,33 & 27285,17 & & & & \\
\hline Aplication Dosage(D) & 2 & 5352,33 & 2676,17 & 0,02 & tn & 4,46 & 8,65 \\
\hline $\mathrm{P} \times \mathrm{D}$ & 2 & 124152,33 & 62076,17 & 0,41 & tn & 4,46 & 8,65 \\
\hline Eror (b) & 8 & 1212830,00 & 151603,75 & & & & \\
\hline$\overline{\text { Total }}$ & 17 & 2033860,50 & & & & & \\
\hline
\end{tabular}

According to Table 5. There is no significant differences between the treatment levelsbdosages of EFB application. The best treatment is the E2 level dose applied in oil palm inter row this is due to the dry weight of the root inside $0-20 \mathrm{~cm}$ from the EFB barrier,the E2 application of oil palm inter row has the highest weight. Root weight is dominated in the $0-20$ $\mathrm{cm}$ depth area from the EFB barrier as compared to the root weight in the EFB. So that even though the dry weight of the EFB layer at E1 treatment is higher and the E2 treatment is the lowest one on oil palm inter row, but E2 treatment on oil palm inter row was the best treatment for the total root dry weight.

\section{Conclusion}

EFB application gives improvement for oil palm root growth as compared to the development of oil palm plant roots that are not given EFB although it is not significantly different. The E2 dose level treatment which places application around the oil palm inter row is the ideal treatment for root dry weights. As ameliorant of spodosol soil the level of E2 dose (EFB 35 tons/ha) and placement of EFB on the oil palm inter row is able to maintain soil fertility whether physical or chemical soil which visible by total dry weight of roots. However, EFB application can be an alternative way to improve the oil palm root. 


\section{References}

[1] Adiwiganda, R., A. D. Koedadiri, and Z. Pulungan : Karakterisasi Tanah Spodosol pada Formasi Geologi Minas (Qpmi). Buletin PPKS 1993. Vol. 1 (2) : 163-173 (2003).

[2] Surianto, A. Rauf, Sabrina T. dan Sutarta, E.S.: Karakteristik Tanah Spodosol Sub Group Typic Placorthod pada Sistem Lubang Besar (Big Hole System)dan aplikasi Parit Drainase 2:1 pada Budidaya Kelapa Sawit (Elaeis guineensis Jacq.) di Kabupaten Barito Timur Propinsi Kalimantan tengah - Dalam Desertasi Doktor USU- Rekayasa Horizon Spodik Tanah Spodosol Sub Group Typic Placorthod pada Budidaya Kelapa Sawit (Elaeis guineensis Jacq.) di Kabupaten Barito Timur Propinsi Kalimantan Tengah, Fakultas Pertanian USU (2014)

[3] Santoso, H. S., E. S. Sutarta, W. Darmosarkoro. : Pengelolaan Tanah dan Penggunaan Pupuk NPK Palmo pada Tanah Spodosols di PT. Bumitama Gunaja Agro. Pusat Penelitian Kelapa Sawit. Medan (2013)

[4] Widyastuti H., E. Guharja,N. Sukarno, L.K. Darusman, D.H.Goenadi, dan S. Smith. : Arsitektur akar bibit kelapa sawit yang diinokulasi beberapa cendawan mikoriza arbuskula. Menara Perkebunan, 71(1): 28 - 43. (2003)

[5] Lubis, A. U. : Kelapa sawit (Elaeis guineensis jacq.) di Indonesia. Pusat Penelitian Kelapa Sawit (2008)

[6] Lim K C and Zaharah A. Rahman. : The Effects Oil Palm EmptyFruit Bunches On Oil Palm Nutrition and Yield, and Soil Chemical (2002)

[7] Thomas Fand Rolf H: Oil Palm Management for Large and Sustainable Yields. International Plant Nutrient Institute. Southeast Asia Program. Singapore. (2003)

[8] Machado, R. M. A., Maria do Rosario, G. Oliveira, dan C. A. M. Portas. : Plant and Soil 2003, 255: 333-341.(2002)

[9] Tinker, P. B. : Soil requirements of the oil palm. In R. H. V. Corley, J. J. Hardon, B. J. Wood (Ed.). Oil palm Research. Elsevier Scientific Publishing Company, p. 165 - 181.(1976) 